\title{
Decreasing Prescription Drug Prices: Can Effective Policy InCEntivize Cooperation Between Previously Antithetic SeCtors?
}

\author{
Benjamin E. Brown* \\ TABLE OF CONTENTS
}

I. INTRODUCTION

A. The Issue: Increasing Pharmaceutical Prices

B. Why Prescription Affordability is Important

C. "PhRMA's” Contributions to the Pricing Problem

D. General Outline

II. The Federal Government's Historical AtTEMPts at Controlling Prescription

DRUG PRICES

A. The Legislation

1. Hatch-Waxman Act

2. Patient Protection and Affordable Care Act (“ACA”) (“ObamaCare”)

B. The Judiciary (FTC v. Actavis)

III. CONTRIBUTING TO THE CRISIS 168
A. Introduction
B. Patent and Antitrust Laws
C. Generic Pharmaceutical Company Issues
D. Increased Marketing Expenditures

1. Detailing

E. Increasing Costs of Research \& Development

F. Increased Medicare Coverage

IV. Pharmaceutical ProfiteERING.

A. Off-Label Prescription Drug Use

B. Delaying Generic Entry

V. VENTURE PHILANTHROPY 180

A. Potential Abuses

1. Pharmaceutical Companies Creating Their Own Philanthropies Then Funding The

2. Limiting the Field of Ideas to the Ideas Heavily Funded by Corporations 


\section{B. Potential Benefits}

1. Increase Innovation Through Nonprofit Funding of Research and Development

2. Economic Repurposing of Drug

C. Example: Cystic Fibrosis Foundation Collaboration with Vertex Pharmaceuticals

VI. ANALYSIS (PoliCy IMPLEMENTATION)

A. Federal Tax Re-evaluation for Pharmaceutical Representatives

B. Use of Modified Venture Philanthropy

1. Utilizing Private Nonprofit Foundations with "Program-Support” Grants .

2. Creating Own Private, Operating, Foundations

VII. CONCLUSIONS 192

\section{INTRODUCTION}

\section{A. The Issue: Increasing Pharmaceutical Prices}

Each year as the Patient Protection and Affordable Care Act's ("ACA") enrollment period commences, and millions of Americans attain the mandated health insurance coverage, more consumers are becoming familiar with the increasing prices of health care. In fact, it was estimated "[t]he United States spent \$2.9 trillion on health care in 2013, or about \$9,255 per person." For 2013, the Center for Medicaid and Medicare Services ("CMS") indicated the third biggest health care expense was prescription drugs. ${ }^{2}$ Then in 2014, similar studies revealed that increasing health care costs were subsequently linked to price inflation of prescription drugs. ${ }^{3}$

* J.D. Candidate, 2018, Indiana University-Robert H. McKinney School of Law; M.P.H. Candidate, 2018, Indiana University - Purdue University Indianapolis Fairbanks School of Public Health; B.S., 2013, Indiana University.

${ }^{1}$ Jason Millman, Here's Exactly How the United States Spends \$2.9 Trillion on Health Care, The WAshington Post, (Dec. 3, 2014), http://www.washingtonpost.com [https://perma.cc/X8D9-8A5V].

${ }^{2} I d$.

${ }^{3}$ Shelby Livingston, Prescription Drugs to Lead Trend of Health Care Price Increases, Bus. INS. (Sep. 24, 2015), http://www.businessinsurance.com [https://perma.cc/6S83-NQ3D]. 


\section{B. Why Prescription Affordability is Important}

The trend of increasing drug prices and their related expenses is likely to persist into the near future. ${ }^{4}$ Elderly Americans aged sixty and older are more likely to be prescribed medications than all other age ranges. ${ }^{5}$ With about 77.3 million "baby-boomers" ${ }^{\text {"6 }}$ aging and the elderly population (ages 65 and older) predicted to comprise about $20 \%$ of the U.S. population by 2029, it is foreseeable that more Americans will be exposed to the price inflation of prescription drugs. ${ }^{7}$ It is important to note that the rising prescription drug costs are not just an issue experienced by the baby-boomer population. Increasing prescription drug costs alongside an aging population will create more health care spending which imposes a higher financial burden on all American taxpayers.

\section{C. "PhRMA's” Contributions to the Pricing Problem}

As nearly seven of ten Americans utilize prescription drugs, large pharmaceutical companies have found several ways capitalize on the ever-growing market of prescription drug users. ${ }^{8}$ Among pharmaceutical manufacturers, the most apparent profiteering measures are generally delaying generic entry, and advocating unapproved prescription drug use through sales representatives. ${ }^{9}$ Together these legal measures create opportunities for pharmaceutical manufacturers to raise prices of their prescription drugs to the highest per capita prices of any nation in the world. ${ }^{10}$

\section{General Outline}

Increasing prescription drug prices have been at the forefront of health care reform for decades, as they have become instrumental to healthy living. This Note will summarize the important historical developments, and the subsequent market responses that have created a conflict between affordability, innovation, and profitability. Part II and III of this note will explore

${ }^{4}$ Matt Dunning, Health Premium Cost Trends Steady For 2015, But Drug Costs Expected To Rise, Bus. Ins. (Oct. 3, 2014, 3:07 PM), http://www.businessinsurance.com [https://perma.cc/38EU-LJDL].

${ }^{5}$ See generally Bill Hendrick, Study Shows About 48\% of Americans Take at Least One Prescription Drug, WeBMd (Sept. 2, 2010), http://www.webmd.com [https://perma.cc/QQ25L78N]. (Noting " $88.4 \%$ of Americans age 60 and over used at least one prescription drug" compared to the second highest $48.3 \%$ of people between 20 and 59.)

6 See generally Susan M. Heathfield, Baby Boomers, ABOUTMONEY.COM, http://humanresources.about.com [https://perma.cc/9KND-V7A4] (last visited Oct. 28, 2015) (“[Baby] Boomers were born between 1944 and 1964”).

${ }^{7}$ Kevin Pollard \& Paola Scommenga, Just How Many Baby Boomers Are There?, Population REFERENCE BUREAU (Apr. 2014), http://www.prb.org [https://perma.cc/S7GJ-65J4].

${ }^{8}$ Nearly 7 in 10 Americans Take Prescription Drugs, Mayo Clinic, Olmsted Medical Center Find, MAYO CLINIC (Jun. 19, 2013), http://newsnetwork.mayoclinic.org/ [https://perma.cc/3JTQUB9R].

9 Alex Tabarrok, The Good News on FDA and ANDAs, MARGINAL REVOLUTION (Feb. 26, 2016, 7:19 AM), http://marginalrevolution.com [https://perma.cc/JT9B-R67W].

10 Pharmaceutical Spending, OECD (2014), available at http://www.oecd-ilibrary.orgen [https://perma.cc/J5WV-59LX]. 
the federal policies in place, and the subsequent market responses that continue to spur high prescription drug prices, respectively. Part IV will further investigate modern techniques pharmaceutical companies are utilizing in order to maximize profits. Part $\mathrm{V}$ will then analyze the benefits and potential abuses that may stem from the emerging concept of "venture philanthropy" in pharmaceuticals. And finally, Part VI will advocate for the implementation of federal policy that will limit marketing expenses while incentivizing a strategic use of the venture philanthropy model, analyzing the positive and negative effects of each in the process. ${ }^{11}$

\section{The Federal Government’s Historical Attempts at CONTROlling Prescription Drug PRICES}

\section{A. The Legislation}

\section{Hatch-Waxman Act}

In order to increase competition and inspire competitive pricing, Congress passed The Drug Price Competition and Patent Term Restoration Act of 1984 ("Hatch-Waxman Act"). Under the act a generic manufacturer may file an Abbreviated New Drug Application ("ANDA") specifying that the generic has the "same active ingredients as," and is "biologically equivalent" to, the already-approved brand-name drug. ${ }^{12}$ This resulted in increased ANDA applications, as well as a high success rates for patent invalidation, ultimately resulting in more generic products competing in the marketplace. ${ }^{13}$

Since the enactment of the Hatch-Waxman Act virtually all top-selling brand name drugs not covered by patent face generic competition, whereas pre-Hatch-Waxman Act, only $35 \%$ of brand name drugs had generic counterparts available. ${ }^{14}$ In general generic prices are approximately $60 \%$ or less than brand name prices. ${ }^{15}$ Overall, there have been some reduced returns on new drugs, but product life cycles have not changed significantly. ${ }^{16}$

${ }^{11}$ For the purpose of the IRS tax code, every "organization that qualifies for tax exemption as an organization described in section 501(c)(3) is a private foundation." 26 U.S.C.A. $\S 501(c)(3)$ (2015). Therefore, "nonprofit organizations" and "private foundations" may be used interchangeably pursuant to the quoted authority in the remainder of this Note.

1221 U.S.C.S. $\S \S 355(\mathrm{j})(2)(\mathrm{A})(\mathrm{ii})$, (iv)(2016).

${ }^{13}$ Martha M. Rumore, The Hatch-Waxman Act--25 Years Later: Keeping the Pharmaceutical Scales Balanced, PHARMACY TIMES (Aug. 15, 2009), http://www.pharmacytimes.com [https://perma.cc/CW7M-AB3Q].

${ }^{14}$ Id.

${ }^{15} \mathrm{Id}$.

${ }^{16} I d$. 


\section{Patient Protection and Affordable Care Act ("ACA")(“ObamaCare”)}

\section{a. The pharmaceutical tax}

In 2010, with passage of the ACA, pharmaceutical companies were introduced to a new fee schedule ${ }^{17}$ pursuant to complex provisions in Title IX. ${ }^{18}$ Section 9008 of Title IX imposes a tax on the pharmaceutical industry based on the revenue from sales of brand-name prescription drugs. ${ }^{19}$ The taxes are then collected by the Treasury Department and allocated to the "Federal Supplementary Medical Insurance Trust Fund" set up by ACA to support health insurance coverage. ${ }^{20}$ The Trust Fund is then used to supplement Medicare Part B benefits, as an effort to maintain a low tax rate for the Medicare social program. ${ }^{21}$

The fee schedule has been the subject of much controversy because of the convoluted manner in which the fee is calculated. ${ }^{22}$ Broadly, Section 9008 calculates fees for a pharmaceutical manufacturer by taking the manufacturer's "sales taken into account" and dividing it by the "aggregate sales taken into account." 23 The result of the fraction is then multiplied by the yearly applicable amount set forth by Section $\S$ 9008(a)(4). "Sales taken into account" is calculated by finding the sum of all prescription drug sales to government programs then multiplying it by a percentage based on a fee schedule. "Aggregate sales taken into account" is provided by the IRS since it requires an aggregate sum of all covered entities. ${ }^{25}$ Although nuanced, generally, the more brand-name prescriptions sold, the more that pharmaceutical company will be taxed. ${ }^{26}$

Pharmaceutical company critics contest that companies with distribution agreements will need to address responsibility for payment of the taxes in license and distribution agreements, and address issues such as joint and several liability. ${ }^{27}$ Proponents also argue that since the government

${ }^{17}$ An annual fee on each covered entity engaged in the business of manufacturing or importing branded prescription drugs.

18 Sheppard Mullin, New Taxes for Pharmaceutical and Device Manufacturers/Importers/Distributors, FDA L. BLOG (Apr. 19, 2010), http://www.fdalawblog.com [https://perma.cc/MCZ5-NBQ9].

${ }^{19} \mathrm{Id}$.

${ }^{20} I d$.

21 Centers for Medicare \& Medicaid Services, Office of the Actuary. Estimated Financial EfFects of the "Patient Protection And AfFordable CARE Act," As Amended, 2-3 (Apr. 20, 2015), https://www.cms.gov/ [https://perma.cc/J4PE-YU2N] [hereinafter CMS, PPACA].

${ }^{22}$ Mullin, supra note 18.

${ }^{23}$ Patient Protection and Affordable Care Act, 42 U.S.C.A. § 9008(b) (2010); see also Annual Fee Imposed on Prescription Drug Manufacturers and Importers, IRS.GOV, https://www.irs.gov/ [https://perma.cc/CP9E-ZDF8] (last visited Feb. 13, 2016) [hereinafter Annual Fee].

24 See generally Peter S. Reichertz, New Taxes for Pharmaceutical and Device Manufacturers/Importers/Distributors, FDA L. BLOG (Apr. 19, 2010), http://www.fdalawblog.com [https://perma.cc/97KB-PDLZ] (Medicare, Veteran Affairs programs, Department of Defense programs, TriCare pharmacy programs, etc.).

\footnotetext{
${ }^{25} I d$.

${ }^{26} \mathrm{Id}$.

${ }^{27}$ Id.
} 
programs are doing the reporting, there should be an opportunity to verify if the information is correct against the covered entities' records. ${ }^{28}$ However, because this could foreseeably cause a delay in payments made to the Medicare trust fund, the IRS established a dispute process through the CMS. ${ }^{29}$ Despite potential concerns, CMS projects that, between 2010 and 2019, Section 9008 will save approximately $\$ 26$ billion. ${ }^{30}$ Further, this sales tax encourages pharmaceutical manufacturers to reduce prices in order to reduce paying taxes at a heightened rate. ${ }^{31}$

\section{b. National physician payment transparency program (“Open Payments”)}

The ACA includes a lesser-known provision, called the "National Physician Payment Transparency Program," commonly known as the "Sunshine Act" or "Open Payments."32 CMS published a final rule on February 8, 2013, which requires that manufacturers of drugs report payments or other transfers of value to physicians and teaching hospitals. ${ }^{33}$ The final rule also requires manufacturers and group purchasing organizations ("GPOs") to disclose physician ownership or investment interests. ${ }^{34}$ They must also disclose what they pay to doctors for purposes such as consulting or speaking on behalf of the manufacturer or a specific drug. ${ }^{35}$

\section{c. Congressional funding of research \& development}

Surprisingly, pharmaceutical research and development investments are supported by hefty government subsidies and nonprofit investments. ${ }^{36}$ The CBO noted that "out of 21 of the most influential drugs introduced between 1965 and 1992, only five were essentially developed entirely by the private sector." 37 Furthermore, health-related research is the second largest recipient of federal funding. ${ }^{38}$ However, the government receives no feedback on how the funds are allocated. ${ }^{39}$ Ultimately, even though revenue from existing brand-name drugs and government subsidies help

${ }^{28} I d$.

${ }^{29}$ Patient Protection and Affordable Care Act, 42 U.S.C.A. § 9008(b) (2010); see also Annual Fee Imposed on Prescription Drug Manufacturers and Importers, IRS.GOV, https://www.irs.gov/ [https://perma.cc/CP9E-ZDF8] (last visited Feb. 13, 2016).

${ }^{30}$ CMS, PPACA, supra note 21.

${ }^{31}$ See id.

${ }^{32}$ Marketing and Direct-to-Consumer Advertising ("DTCA”) of Pharmaceuticals, NAT'L CONF. ST. LEGIS. (July 1, 2015), http://www.ncsl.org [https://perma.cc/L5N8-583H].

33 See generally Open Payments, CENTER FOR MEDICARE \& MEDICAID SERVICES, https://www.cms.gov/openpayments/ [https://perma.cc/RU8W-2NL7] (last visited Jan. 9, 2016).

${ }^{34} \mathrm{Id}$.

${ }^{35} \mathrm{Id}$.

${ }^{36}$ See generally Cong. Budget OfFice, Research And DEVElopment In THE United StATES 27 (October 2006), http://www.cbo.gov [https://perma.cc/4Q74-H7TX].

${ }^{37}$ Id. at 27 n. 1 .

${ }^{38}$ Id. at 27.

${ }^{39}$ See generally id at 27-41. 
fund new drugs still in testing, pharmaceutical manufacturing executives still attribute the substantial increase in prescription drug prices to research and development costs. ${ }^{40}$

\section{B. The Judiciary (FTC v. Actavis)}

While policymakers continued to attempt to slow down the increasing costs of prescription drugs, the Supreme Court of the United States decided FTC v. Actavis. Candidly, the Actavis case focused on the issue of whether brand name prescription drugs could pay generic drug companies to not enter a market, a tactic known as "reverse-payment settlements." 41

In FTC v. Actavis, the Federal Trade Commission ("FTC") filed a complaint alleging that reverse payment settlements between holders of a drug patent and potential generic manufacturers of the disputed drug, were unfair restraints on trade that violated federal antitrust laws. ${ }^{42}$ In a five to three decision, the Court held that the reverse payment settlements "can sometimes violate the antitrust laws." ${ }^{43}$ In so holding, the Court also asserted that reverse-payments must pass the present "rule of reason" antitrust laws in order to be upheld. ${ }^{44}$ More importantly however, the Supreme Court determined FTC then has the heavy burden of proving in each case whether the severity of the reverse-payment settlement brings about anticompetitive effects. ${ }^{45}$ As a result, these settlements become nullified if the resource-restricted FTC decides to engage in costly litigation. ${ }^{46}$ Thus, brand-name prescription drug companies are still permitted to deter generic competitors from entering the markets so long as the settlements are not brought to the attention, and deemed worthy of litigation, by the FTC. ${ }^{47}$

\section{CONTRIBUTING TO THE CRISIS}

\section{A. Introduction}

As a country, the United States prides itself on capitalism in order to promote competitive markets, spur innovation, and accumulate capital. ${ }^{48}$ Few industries, if any, have benefited more

40 Robert Langreth, Big Pharma's Favorite Prescription: Higher Prices, BloOMBERG Bus. (May 8, 2014), http://www.bloomberg.com/ [https://perma.cc/2VJJ-G3WG]; see also Richard Anderson, Pharmaceutical Industry Gets High Off of Fat Profits, BBC News (Nov. 6, 2014), http://www.bbc.com/news/business-28212223 [https://perma.cc/SD49-ZRJT] (C.E.O. of Pfizer justifying prescription drug prices by stating they still fairly reflect their research and development costs).

${ }^{41}$ F.T.C. v. Actavis, Inc., 133 2223, 2227-38 (2013).

${ }^{42}$ Id.

43 Allison A. Schmitt, Competition Ahead? The Legal Landscape For Reverse Payment Settlements After Federal Trade Commission v. Actavis, Inc., 29 BERKELEY TECH. L.J. 493, 511 (2014) (Qouting F.T.C .v. Actavis, Inc., 133 S. Ct. 2223, 2225 (2013)).

${ }^{44}$ Id. (Quoting F.T.C .v. Actavis, Inc., 133 S. Ct. 2223, 2236 (2013)).

${ }^{45}$ F.T.C., 133 S. Ct. at 2237-38.

${ }^{46}$ Id.

${ }^{47}$ See Schmitt, supra note 43, at 517-518.

${ }^{48}$ Meyer Weinberg, A Short History of American CAPitalism (New History Press 2003), http://www.newhistory.org/CH01.htm [https://perma.cc/73Q4-3NKW]. 
from the United States resting on its capitalistic laurels than have the pharmaceutical industry. ${ }^{49}$ The increasing prices of prescription drugs has pushed profit margins into double-digits for the top five United States-based pharmaceutical companies. ${ }^{50}$ Because of their for-profit nature, pharmaceutical companies are incentivized to develop drugs that will provide their shareholders with the most return on investment. ${ }^{51}$ However, the recent price increase in prescription drugs cannot solely be attributed to the profit initiative. In the following sections, this Note will briefly explore how patent and antitrust laws, generic pharmaceutical blunders, increased research and development costs, and ballooning marketing expenditures contribute to the increase in prescription drug prices.

\section{B. Patent and Antitrust Laws}

Patent and antitrust laws are generally thought of as promoting fair competition by banishing collusion and agreements that act in the "restraint of trade." 52 Although both types of laws are distinct from the one another, patent and antitrust tend to coincide in regards to the pharmaceutical industry. ${ }^{53}$ Patents protect against competition by [copycat] drugs for a period of about 20 years. ${ }^{54}$ During this 20-year period, a pharmaceutical company has exclusive control of a particular drug, and the initial price of the drug is raised in order to compensate for the expected profit that will be lost when the patent expires. ${ }^{55}$ This period of increased prescription drug prices prior to patent expiration is known as the "patent cliff." 56

In 2013, "inflated prices of existing brand-name prescription drugs accounted for about $\$ 20$ billion of the industry's sales growth." because of patent expirations." 58 With the expiration of patents and the resulting loss of revenue,

49 See generally Pharmaceutical Industry, World HEALTH OrG. (2015), http://www.who.int/trade/glossary/story073/en/ [https://perma.cc/NQK3-5ZCE] [hereinafter Pharmaceutical Industry] ("The global pharmaceuticals market is worth $\$ 300$ billion a year ... [t] he 10 largest drugs companies control over one-third of this market, several with sales of more than US $\$ 10$ billion a year . . . Six are based in the United States . . .") (last visited Mar. 10, 2016).

${ }^{50}$ Anderson, supra note 40.

${ }^{51}$ Pharmaceutical Industry, supra note 49.

${ }^{52}$ Addyston Pipe \& Steel Co. v. United States, 175 U.S. 211, 212 (1899).

${ }^{53}$ Linda Nussbaum \& John Radice, Pharmaceutical Antitrust: Delayed Generic Entry Cases 1, 2 (Dec. 7, 2011), http://www.antitrustinstitute.org [https://perma.cc/75F6-YGVZ].

${ }^{54}$ Frequently Asked Questions on Patents and Exclusivity, U. S. FoOD \& DRUG AdMIN. (last updated July 18, 2014), http://www.fda.gov/ [https://perma.cc/8H3L-LK4L].

55 Anup Shah, Pharmaceutical Corporations and Medical Research, GLOBAL ISSUES (Oct. 2, 2010), http://www.globalissues.org/ [https://perma.cc/66PU-U92K].

56 Jack DeRuiter \& Pamela L. Holston, Drug Patent Expirations and the "Patent Cliff", 37(6) U.S. PHARMICIST 12, 12-20 (Jun. 12, 2012), http://www.uspharmacist.com/ [https://perma.cc/F5Z6-TNNS].

${ }^{57}$ Langreth, supra note 40.

${ }^{58}$ Id. 
pharmaceutical companies attempt to deter generic manufacturers from entering their market, toeing the legal boundaries of antitrust issues. ${ }^{59}$

With growing frequency, companies with older drugs are boosting prices when rivals show up, "either to match the price of the newer drug or to make up for profits lost to the competitor." 60 However, some pharmaceutical companies actively seek to prevent competition in their particular drug market by attempting to restrict distribution. Due to the contribution of initial patent, antitrust protections, and profit maximization incentives, drug price inflation "is about as fast as it has ever been for as long as it has ever been." 61

\section{Generic Pharmaceutical Company Issues}

In 1984, the United States government helped launch the generic pharmaceutical industry with the passage of the Hatch-Waxman Act ("HWA"). ${ }^{62}$ Individually, generic pharmaceutical companies are often much smaller than their brand-name counterparts, and a majority operate within a niche in the pharmaceutical industry. Although small, generic pharmaceutical companies and their products fill about $80 \%$ of the prescriptions dispensed. ${ }^{63}$ It is estimated that between 2003 and 2013, generic products have saved the United States health system nearly $\$ 1.5$ trillion, by introducing cheap and effective drugs. ${ }^{64}$

Despite its successes, the generic pharmaceutical industry has also contributed to the increased cost of prescription drugs due to major company consolidations, poor manufacturing practices, and drug shortages. ${ }^{65}$ Trending consolidations amongst generic pharmaceutical companies has led to less competition and the potential for price gouging. ${ }^{66}$ To illustrate, just three companies, Mylan, Teva and Actavis, generated $44 \%$ of generic drug revenue around the world. ${ }^{67}$ Additionally, several large generic drug makers have gotten into trouble with the FDA because of bad manufacturing practices. ${ }^{68}$ As a result, some key products such as anesthetics, chemotherapeutic

59 Janet A. Gongola, Note, Prescriptions For Change: The Hatch-Waxman Act And New Legislation To Increase The Availability Of Generic Drugs To Consumers, 36 InD. L. REV. 787 , 798 (2003).

${ }^{60}$ Langreth, supra note 40.

${ }^{61}$ Robert Langreth, Drug Prices Defy Gravity, Doubling or Dozens of Products, BLOOMBERG (Apr. 30. 2014, 10:00 PM) http://www.bloomberg.com [https://perma.cc/DN2N-VQSA].

${ }^{62}$ The Industry, GENERIC PHARM. Ass'N, http://www.gphaonline.org [https://perma.cc/VD8R4GR7] (last visited Mar. 10, 2016).

${ }^{63} \mathrm{Id}$.

64 Generic Pharm. Ass'n, Generic Drug Savings in the U.S. 1, 1 (6th ed. 2014), http://www.gphaonline.org/ [https://perma.cc/3BF7-N387].

${ }^{65}$ Terry Graedon. Be Wary of Stratospheric Increases in Generic Drug Prices, ThE PEOPLE's PHARMACY (Jan. 6, 2014), http://www.peoplespharmacy.com [https://perma.cc/ET4M-QHXX].

${ }^{66} \mathrm{Id}$.

${ }^{67} \mathrm{Id}$.

${ }^{68}$ Joe Graedon. Expose Reveals Why We No Longer Trust All Generic Drugs, ThE PeOPLE’S PHARMACY (Dec. 3, 2014), http://www.peoplespharmacy.com/ [https://perma.cc/8G4Y-95S6]. 
agents, antibiotics, nutrients for malnourished infants, painkillers and even intravenous solutions from abroad have been banned, further contributing to shortages and higher prices. ${ }^{69}$

\section{Increased Marketing Expenditures}

Although it is demonstrable that high research and development prices are part of the reason for increasing prescription drugs, a closer look at expenditures would indicate that research and development expenses are dwarfed by massive marketing expenses.

Drug companies justify the high prices they charge by arguing that their research and development ("R\&D") costs are huge. On average, only three in 10 drugs launched are profitable, with one of those going on to be a blockbuster with $\$ 1$ bn-plus revenues a year. Many more do not even make it to market. But . . . drug companies spend far more on marketing drugs-in some cases twice as muchthan on developing them. ${ }^{70}$

Pharmaceutical companies advertise through consumer-directed advertising and physiciandirected, commonly referred to as "detailing." "71 Consumer-directed advertising is strictly regulated and researched by the FDA. ${ }^{72}$ Detailing, on the other hand, is governed by highly arbitrary and unenforceable guidelines created by the American Medical Association ("AMA") and other professional groups which allow the industry to promulgate self-imposed guidelines. ${ }^{73}$

\section{Detailing}

Pharmaceutical marketing of prescription drugs, especially to physicians, has been a complex issue which continues to perplex policymakers as national health care expenditures continue to boom. Pharmaceutical companies spend an estimated twelve to fifteen billion dollars on promoting their products, with nearly $84 \%$ of that amount directed toward "detailing," which includes the gifts and samples given to physicians. ${ }^{74}$ In efforts to construct effective legislation, policymakers

${ }^{69}$ Margaret Clapp, Michael A. Rie, \& Phillip L. Zweig, How a Cabal Keeps Generics Scarce, N.Y. TIMES (Sept. 2, 2013), http://www.nytimes.com [https://perma.cc/8JBU-2VMG].

${ }^{70}$ Anderson, supra note 40; see also, Robert Langreth, supra note 61.

${ }^{71}$ Scott Velasquez, There Ain't No Such Thing as a Free Lunch: A Look at State Disclosure Laws and the Effect on Pharmaceutical Company Marketing, 41 J. MARSHALL L. REV. 563 (2008); see also Amanda L. Connors, Big Bad Pharma: An Ethical Analysis of Physician-Directed and Consumer-Directed Marketing Tactics, 73 Alb. L. Rev. 243, 244 (2009).

72 The Impact of Direct-to-Consumer Advertising, FDA.GOV, http://www.fda.gov/Drugs/ResourcesForYou/Consumers/ucm143562.htm [https://perma.cc/3QP7-UKTV] (last updated Oct. 23, 2015). Due to a comprehensive regulatory scheme governing consumer-advertising, a complete discussion of the subject would be outside the scope of this Note and is therefore omitted.

73 Amanda L. Connors, Big Bad Pharma: An Ethical Analysis of Physician-Directed and Consumer-Directed Marketing Tactics, 73 ALB. L. REV. 243, 244 (2009).

${ }^{74} \mathrm{Id}$. at $253-254$. 
have attempted to limit certain expenditures on detailing in order to curb prescription drug price spikes. $^{75}$

Generally, there are three types of detailing that health care professionals engage in: 1) traditional detailing; 2) academic detailing; and 3) the increasingly popular "e-detailing." most prevalent type of detailing is "traditional detailing" which is typically performed by pharmaceutical sales representatives. ${ }^{77}$ According to the Pharmaceutical Marketing Network, "“[d]etail[ing]' means that part of an in-person, face-to-face sales call during which a Sales Representative ... [makes] use of the applicable promotional materials [and] makes a presentation of such [p]roduct to a medical professional with prescribing authority." 78 Common promotional activities include distributing samples, informational physician meals, and giving of gifts such as medical textbooks. ${ }^{79}$ Just after the enactment of the ACA, "prescription drug companies [would] spen[d] an average of $\$ 8,290$ per physician to maintain a relationship through visits from sale representatives, distribution of free samples, and explanations of results from recent drug trials. ${ }^{~} 80$ Further, pharmaceutical representatives traditional detailing accounted for about $76 \%$ or $\$ 20.7$ billion of all pharmaceutical marketing expenditures. ${ }^{81}$

In an attempt to curb this otherwise ghastly expense, three states-Vermont, New Hampshire, and Maine-have attempted to pass legislation that would limit detailing efforts. ${ }^{82}$ The limitation of traditional detailing reached its pinnacle in Sorrell v. IMS Health, in which a Vermont statute restricted the sale, disclosure, or use of pharmacy records that reveal the prescribing practices of individual doctors by pharmaceutical representatives ${ }^{83}$ Writing for the Court, Justice Kennedy reasoned that the statute was designed to impose a specific, content-and speaker-based burden on a protected expression, warranting heightened judicial scrutiny in determining whether it violated

75 See generally Health Care Costs: A Primer, The KAISER FAM. Found. (May 1, 2012), http://kff.org/report-section/health-care-costs-a-primer-2012-report/ [https://perma.cc/NH7E2VC7].

76 Margaret Rouse, Pharmaceutical Detailing Definition, TechTARget (Feb. 2011), http://searchhealthit.techtarget.com/definition/detailing [https://perma.cc/7E3M-JTWX].

${ }_{77}^{77}$ Connors, supra note 73, at 255-56.

78 The Pharma Marketing Glossary, The Pharma MARKeting NeTwork, http://glossary.pharma-mkting.com/detailing.htm [https://perma.cc/JQ67-R7J5] (last visited Jan. 7, 2016).

${ }^{79}$ Prescription Project, Persuading the Prescribers: Pharmaceutical Industry Marketing and its Influence on Physicians and Patients, the Pew Charitable Trusts (Nov. 11, 2013), http://www.pewtrusts.org/ [https://perma.cc/MTX6-ZMM9].

${ }^{80}$ Melissa N. Hoffman, Pharmaceutical Detailing Is Not For Everyone: Side Effects May Include Sub-Optimal Prescribing Decisions, Compromised Patient Health, And Increased Prescription Drug Spending, 33 J. Legal MeD. 381, 384 (2012).

${ }^{81}$ Prescription Project, supra note 79 (this information was provided in the article and I used the following calculation to come up with the $76 \%$ or 20.7 Billion).

${ }^{82}$ Gayland O. Hethcoat II, Regulating Pharmaceutical Marketing After Sorrell v. IMS Health Inc., 15 QUINNIPIAC HEALTH L.J. 187, 188 (2012).

${ }^{83}$ Sorrell v. IMS Health Inc., 564 U.S. 552 (U.S. 2011). 
First Amendment free speech protections. ${ }^{84}$ Under this heightened scrutiny, the statute limiting commercial free speech was unconstitutional. ${ }^{85}$

Because of the Court's holding in Sorrell v. IMS Health, and its apparently broad implications protecting commercial free speech, states such as Vermont, New Hampshire, Maine, Pennsylvania, and West Virginia have resorted to counter-detailing, better known as academic detailing. ${ }^{86}$ In academic detailing, "health care professionals . . . educate prescribers about new prescriptions." 87 This program differs from traditional detailing by eliminating the financial incentive created by pharmaceutical sales representatives. ${ }^{88}$ By using unbiased health care professionals, states that enact such programs intend to educate providers about alternative cost-efficient and effective medication. ${ }^{89}$

Although proven ineffective in other developed countries, some experts express doubts surrounding academic detailing programs. ${ }^{90}$ Experts argue that "[a] publically funded education program . . . may fail 'as a matter of simple economics." "91 Pharmaceutical companies spend billions annually on detailing, so "the state would need to commit enormous resources to convey a contrary message." 92 Further, requiring states to participate, create, and fund health care entities has proven to be unpopular among various states. ${ }^{93}$ Therefore, by leaving academic detailing to be established by states or federally mandating their creation, the programs may face resistance and thus ineffective implementation or funding of their plans. Without a vast majority of states enacting academic detailing programs overall effectiveness in lowering prescription drug prices seen abroad may not be realized.

Aside from traditional detailing and academic detailing, health care professionals use the Internet to build one-on-one relationships with physicians via social networks, web links, and live virtual discussion-such as Skype. ${ }^{94}$ E-detailing has become an increasingly preferred medium of communication and is used to field doctor's questions about certain products. ${ }^{95}$ Further, because

${ }^{84}$ Id. at 2653.

${ }^{85} \mathrm{Id}$.

${ }^{86}$ Kevin B. O'Reilly, New Reps, New Rap: The Counter-Detailers, AMEDNEws.COM (Sept. 24, 2007), http://www.amednews.com [https://perma.cc/23B6-2ANU].

${ }^{87}$ Rouse, supra note 76.

${ }^{88}$ Id.

89 Prescription Drugs: Academic Detailing, COMMUNiTy CATALYst, http://www.communitycatalyst.org/ [https://perma.cc/LHR6-976V] (last visited Jan. 8, 2016).

${ }^{90}$ See id. ("The National Prescribing Service (NPS) in Australia generated a net savings of \$293 million Australian dollars over a ten-year period . . . academic detailing is their most effective component").

${ }^{91}$ Hethcoat, supra note 82, at 206.

92 Id.

93 See generally Angela Hoover, Resistance to Affordable Care Act Continues Nationwide, Health \& Wellness Magazine (Jun. 1, 2013), http://healthandwellnessmagazine.net/ [https://perma.cc/AF8R-RRTC].

${ }_{94}$ Rouse, supra note 77.

95 Sales Innovation and Metric Report, 2014, EYE FOR PHARMA (2014), http://www.eyeforpharma.com/ [https://perma.cc/Y3VB-9UQF]. 
e-detailing uses live virtual discussions, both the physician and the pharmaceutical sales representatives do not have to accumulate traveling expenses for face-to-face meetings. ${ }^{96}$

\section{E. Increasing Costs of Research \& Development}

As tension between public interest in innovation and affordability continues to mount, many American consumers are becoming dissatisfied with high prices and the perceived lack of curative drugs. ${ }^{97}$ However, the pharmaceutical industry and some scholars assert that the increasing costs associated with bringing a drug to market due to regulation are the primary reason why there has been a sizeable increase in prescription drug prices. ${ }^{98}$ This assertion is supplemented by an estimated 200\% increase in drug development costs from 2004 to $2013 .{ }^{99}$ In studying the increase of development costs, the Congressional Budget Office ("CBO") advanced five underlying factors that contribute to increasing research and development prices which illustrate the increase:

$[(1)]$ an increase in the percentage of drug projects that fail in clinical trials[; (2)] a trend toward bigger and lengthier clinical trials ... [; (3)] a possible rise in the number of trials that firms are conducting; ... . [(4)] and a shift in the types of drugs that companies work on, toward those intended to treat chronic and degenerative diseases[; and (5) valuation]. ${ }^{100}$

In developing a new drug, a drug manufacturer must pass three phases of clinical trials each with various requirements promulgated by the FDA. ${ }^{101}$ These phases, commonly referred to as "milestones" by the manufacturers, can be characterized as: phase one testing for safety in a small sample of healthy human volunteers; phase two testing for safety in a larger sample of those with the condition to be treated; and phase three testing on the largest scale to identify efficacy and sideeffects. ${ }^{102}$ Assuming the drug progresses through each milestone, costs grow exponentially while the probability of the manufacturer recouping its $\$ 1.5$ billion investment remains below $50 \%{ }^{103}$ Further, considering there is about a $12 \%$ chance of a drug successfully making it through all phases, pharmaceutical manufacturers may be spending more for "larger and lengthier trials" to increase the probability of their new drug's success. ${ }^{104}$

Additionally, the CBO's report stated that pharmaceutical manufacturers are shifting toward developing prescription drugs that treat chronic and degenerative illnesses. ${ }^{105}$ Further, the CBO

${ }^{96}$ Id. at 13 .

97 Congressional Budget OfFice, supra note 37.

98 Jaime d'Almeida et al., Feature, Drug Development R\&D: New Transaction Structures, 33

DEL. LAW. 18, 19 (2015).

${ }^{99} \mathrm{Id}$.

${ }^{100}$ CONG. Budget OfFice, supra note 37, at 22.

101 d'Almeida et al., supra note 98, at 20.

${ }^{102}$ CONG. Budget OfFice, supra note 37, at 22-23.

103 d'Almeida et al., supra note 98, 19-20.

${ }^{104}$ Medicines: Costs in Context, PHRMA, http://www.phrma.org/cost [https://perma.cc/ZAP9QPEM] (last visited Aug, 17, 2016).

${ }^{105}$ Cong. Budget OfFICE, supra note 37, at 24. 
reasoned that since chronic illness drugs "take longer to achieve measurable results, they may require bigger and more expensive trials. . . [and] because such drugs are meant to be taken for a long time, they must be tested for side effects over a longer period." 106 However, of the 3,400 new medicines currently in development in the United States, only 8\% (435) are being developed for the purpose of treating fifteen leading chronic conditions. ${ }^{107}$ Conversely, PhRMA avers that it is the growing regulations are causing longer developments: "the form used by researchers to collect data from each patient expanded in length [of drug development] by 227\% between 2000 and 2011 , reflecting the growing challenges of conducting clinical trials." 108

In 2014, pharmaceutical manufacturers provided about $60 \%$ funds for prescription research while the federal government funded about 30\%, and the other $10 \%$ coming from various nongovernment agencies. ${ }^{109}$ In total, PhRMA expended $\$ 51.2$ billion on research and development for the same year. ${ }^{110}$ Also, PhRMA stated that members gave $24 \%$ of their previous sales to fund further research and development. ${ }^{111}$ Conservatively, assuming that the largest six of the twentynine biggest United States pharmaceuticals had sales worth \$10 billion each, PhRMA would have aggregately invested about $\$ 14.4$ billion from sales profits. ${ }^{112}$ Comparatively, in providing funding for a third of all research and development expenses the federal government would have granted $\$ 15.36$ billion.

Finally, research and development expenditures are not valued the same way in pharmaceuticals as they are in other industries. ${ }^{113}$ The United States' government notes that the profit margins of the pharmaceutical companies are not as extraordinary as the public seems to think, stating "conventional accounting measures overstate the profitability of the drug industry." "114 The misperception stems from the uniqueness of the pharmaceutical industry and general economic accounting principles. ${ }^{115}$ According to the CBO, "most R\&D outlays as expenditures rather than as investments that add to the value of a firm"; thereby creating omissions in their assets. For research and development intensive industries, such as pharmaceuticals, that omission can significantly over-state profitability."116

\section{F. Increased Medicare Coverage}

\section{Id.}

107 PhRMA, More than 430 New Medicines in Development for Top Chronic Diseases Affecting Older Americans http://www.phrma.org/ [https://perma.cc/2CMC-ZA7X].

108 PHRMA, 2015 Profile: Biopharmaceutical Research Industry 42, http://www.phrma.org/ [https://perma.cc/64XF-KL6G].

109 Katlyn Stone, Who Funds Biomedical Research?, The Balance (Aug. 26, 2016) https://www.thebalance.com/ [https://perma.cc/8HHA-DWUW].

${ }^{110}$ PhRMA Member Companies Invested \$51.2 Billion in R\&D in 2014, PR NEWSWIRE (Apr. 20, 2015), http://www.prnewswire.com [https://perma.cc/BL82-3W84][hereinafter PRNewswire].

${ }^{111} \mathrm{Id}$.

112 Pharmaceutical Industry, supra note 49.

113 PRNewswire, supra note 110.

${ }^{114}$ Cong. Budget OfFICE, supra note 36, at 4.

${ }^{115}$ Id. at 4-5.

${ }^{116}$ Id. at 4. 
Through taxes, Americans who are currently employed finance the increasing costs of senior health care through federal programs such as Medicare. ${ }^{117}$ Simply put, Medicare is a system that relies on payroll taxes, premiums, and general revenues to supplement the seniors drawing Medicare benefits. ${ }^{118}$ Of importance here is the "Medicare Part D" plan the complex prescription drug program that consists of $68 \%$ of Medicare's current enrollees participate in. ${ }^{119}$

Generally, Medicare Part D is funded through three similar means: funds authorized by Congress (74\%); premiums from people enrolled in Medicare Part B (Medical Insurance) and Medicare prescription drug coverage (Part D) (15\%); and interest earned on the trust fund investment (11\%). ${ }^{120}$ Together, these sources of funding comprise Medicare Part D expenditures that accounted for $11 \%$ of the total $\$ 597$ billion of Medicare expenditures in $2014 .{ }^{121}$ Within the next ten years, the per capita spending growth for Medicare Part D $(5.7 \%)$ is expected to be higher compared to that of its larger predecessors Part A (3\%) and Part B $(4.7 \%){ }^{122}$ The Office of the Actuary attributes the higher rates to increasing costs associated with expensive specialty drugs. ${ }^{123}$

In addition to the aging baby boomer population, the decreasing number of private sector employers offering prescription drug plans to retirees is contributing to the Medicare Part D enrollment. ${ }^{124}$ Employers discontinue pharmacy benefits to Medicare-eligible retirees because of the financial burden of prescription drug costs. ${ }^{125}$ According to a recent study, "the percentage of employers that plan to continue offering prescription drug plans to Medicare-eligible retirees has dropped dramatically in the past two years." ${ }^{126}$ Although the drop was predicted by public officials, its occurrence highlights the growing number of Americans whose prescription drugs will need to be covered by the federal government or cease to receive the care they need. ${ }^{127}$

While generic drugs pushed by insurers and the government now makeup $86 \%$ of all medicines used in the U.S., that has not reduced total spending on prescription drugs. ${ }^{128}$ In 2012 , Americans

${ }^{117}$ Robert E. Muffit \& Alyene Senger, Medicare's Rising Cost - and the Need for Reform, THE HeRITAGE Found. (Mar. 22, 2013), http://www.heritage.org/ [https://perma.cc/63M2-427X].

118 The Facts on Medicare and Health Spending and Financing, THE KAISER FAM. FOUND (Jul. 24, 2015), http://kff.org/ [https://perma.cc/BR5M-2RAY] [hereinafter KAISER FAMILY FOUNDATION].

119 CMS Releases Prescriber Data for the First Time, CENTER FOR MEDICAID \& MEDICARE SERVICES (Apr. 30, 2015), https://www.cms.gov/ [https://perma.cc/N49S-S2N2].

120 How is Medicare Funded?, MEDICARE.GOV, https://www.medicare.gov [https://perma.cc/8KEJ-BKYY] (last visited Oct. 28, 2015); MAYO CLINIC, supra note 8, at figure 6.

121 THE KAISER FAM. FOUND, supra note 118.

${ }^{122} \mathrm{Id}$.

${ }^{123} \mathrm{Id}$.

${ }^{124}$ Matt Dunning, Fewer Employers to Offer Retiree Prescription Drug Plans: Survey, Bus. INSIDER (May 30, 2015 2:39pm), http://www.businessinsurance.com [https://perma.cc/ND7TZTC2].

${ }^{125} \mathrm{Id}$.

${ }^{126} \mathrm{Id}$.

${ }^{127}$ Id.

${ }^{128}$ Langreth, supra note 40. 
spent \$263 billion, or $11 \%$ more than the \$236 billion in $2007 .{ }^{129}$ Prior to the enactment of the ACA, employers engaged in Retiree Drug Subsidy ("RDS"), in which if employers that offered prescription drug benefits that were "actuarially equivalent" to Medicare Part D's prescription drug benefits, then the employer would be able to receive tax-breaks. After 2013, the RDS provision was no longer in effect. ${ }^{130}$ One would fathom then, that more retirees may apply to Medicare Part D to cover their prescription drugs.

However, despite recognizing a profit margin that is higher than other successful industries in the United States, factors such as: increased specialization of drugs; the length of development and patent approval processes; and prevalence of insurance coverage, all contribute to the increased demand which would raise prices under all economic models. ${ }^{131}$

\section{Pharmaceutical Profiteering}

\section{A. Off-Label Prescription Drug Use}

Off-label prescription drug use tends to fall into three categories: $\left.{ }^{132} 1\right)$ the dose is significantly higher than the label recommendation; 2) the drug is given for an indication not on the label; and 3 ) the patient is not part of a population included in the clinical trials listed on the label. ${ }^{133}$ Generally, the pharmaceutical sales representative advises physicians about other uses of a prescription drug since it would be illegal for the manufacturer to do so themselves. ${ }^{134}$ In December 2012, the Second Circuit found that promotion of off-label uses by a company sales representative was considered to be protected speech per the First Amendment. ${ }^{135}$

Proponents of off-label prescribing advocate that off-label use achieves two marquee benefits it avoids delay in getting the products to market; and the associated social value of providing a drug that may aid other ailment than otherwise prescribed. ${ }^{136}$ In order for a previously marketed drug to be safely re-marketed for another purpose, it must satisfy rigorous FDA requirements

${ }^{129} \mathrm{Id}$.

${ }^{130} \mathrm{Id}$.

${ }^{131}$ Cong. Budget Office, supra note 36, at 7-8.

132 Steven R. Salbu, Off-Label Use, Prescription, and Marketing of FDA-Approved Drugs: An Assessment of Legislative and Regulatory Policy, 51 FLA. L. REV. 181, 188 (April 1999); see also Liability and Off-Label Prescriptions, 6(2) PsychiATRy (EDGEMONT) 42, 42-44, http://www.ncbi.nlm.nih.gov [https://perma.cc/4YWZ-7YQV] (The third category usually involves children or geriatric patients).

${ }^{133}$ Id.

${ }^{134}$ Stephanie M. Greene \& Lars Noah, Off-Label Drug Promotion and the First Amendment, 162 U. $\quad$ PA. L. REV. ONLINE 239 (2014), https://www.pennlawreview.com/debates/index.php?id=50 [https://perma.cc/FU58-CYJB].

135 Robyn Hagan Cain, Off-Label Use Promotion is Protected Free Speech, FINDLAwBLOG.COM (Dec. 4, 2012, 3:05 PM), http://blogs.findlaw.com [https://perma.cc/H4NF5LTT] (although off-label prescribing has received countless treatment by many scholars, only describing the arguments that will be mentioned later in the policy proposal will be sufficient for this Note).

136 Salbu, supra note 132 , at 193. 
which have been known to take several years. ${ }^{137}$ By prescribing the medication off-label, the physician has the opportunity to increase the quality of patients' lives relatively quickly. ${ }^{138}$

Further, advocates would assert the social value alone is enough to vindicate off-label prescribing. ${ }^{139}$ For instance, certain forms of aspirin are available over-the-counter for mild treatment of pain, and although a relatively old custom, physicians advocate for the use aspirin to reduce the chance of heart attack in at-risk patients. ${ }^{140}$

Conversely, other consumers see the growing trend in off-label prescribing as a way for pharmaceutical companies to increase the demand for their product through marketing to doctors. ${ }^{141}$ Additionally, some consumers assert that because these drugs are not tested according to FDA's standards, utilizing drugs for alternative purposes may fails to alert officials to the increased potential for side effects. Then after the drug goes mainstream the problems are discovered after the side effects have been experienced. ${ }^{142} \mathrm{PhRMA}$, a potential catalyst of the offlabel prescribing trend, supports proper use of medications proffering that prescribed use of medications would save the United States about \$213 billion per year. ${ }^{143}$

\section{B. Delaying Generic Entry}

In October 2015, Turing Pharmaceuticals made headlines for their astronomical price increase of Daraprim, a prescription drug that treats parasitic infections occurring in persons with AIDS/HIV. ${ }^{144}$ Due to the small market and modest profits, other manufacturers decided to pursue other markets. ${ }^{145}$ Theoretically, the price increase and subsequent revenue will lure more competitors to the market and lower the price. ${ }^{146}$ However, Turing restricted their distributions to Walgreens's specialty pharmacy and inquiring hospitals. ${ }^{147}$ By narrowing their distribution network, Turing made it tough for competitors to receive samples and begin relevant research and development for competing products. ${ }^{148}$ Pending any further developments, the Federal Trade

${ }^{137}$ Id. at 198.

138 Judith G. Edersheim, Off-Label Prescribing, PsychiAtriC TIMES (Apr. 14, 2009), http://www.psychiatrictimes.com/ [https://perma.cc/3CW8-N4MZ].

139 Salbu, supra note 132, at 194 ("[i]f off-label use of drugs can help patients, then off-label marketing may enable the greatest number of potential beneficiaries to receive the treatments best suited to their needs.").

${ }^{140} \mathrm{Id}$. at 195.

141 See id. at 195-97.

${ }^{142}$ Id. at 200-04.

143 Medicines: Cost in Context, PHRMA, http://phrma.org/cost [https://perma.cc/W2W4EVFS] (last visited Feb. 13, 2016).

${ }^{144}$ Andrew Pollack, New York Attorney General Examining Whether Turing Restricted Drug Access, N.Y. TIMES (Oct. 12, 2015), http://www.nytimes.com/ [https://perma.cc/5NVU-T8UF] (raised the price of a tablet from $\$ 13.50$ to $\$ 750$ ).

${ }^{145} \mathrm{Id}$.

146 Reem Heakel, Economic Basics: Supply and Demand, INVESTOPEDIA, http://www.investopedia.com [https://perma.cc/U3KP-D4SH] (last visited Mar. 11, 2016).

${ }^{147}$ Pollack, supra note 144.

${ }^{148}$ Id. 
Commission ("FTC") is likely to determine that this anticompetitive behavior violates antitrust laws. $^{149}$

Effectively, Turing Pharmaceuticals employed a different approach to delaying generic entry of a prescription drug in order to maximize their profit after their patent had expired. Although pharmaceutical manufacturers are subject to the antitrust laws, the recent Supreme Court decision in Actavis has allowed for certain situations in which manufacturers can pay competitors to not enter the market. ${ }^{150}$ The Court recognized that "antitrust laws typically prohibit agreements where one company pays a potential competitor not to enter the market. ${ }^{151}$ Allowing the FTC to selectively pursue concerning antitrust cases, will undoubtedly place a heavy and expensive burden on the FTC to exploit these cases and subsequently prosecute them. Thus, some reverse payment agreements may slip through the cracks if they are not particularly egregious.

In addition to reverse payment agreements, pharmaceutical manufacturers have continued to delay generic entry through "sham litigation," "citizen's petitioning," and "product hopping." 152 In sham litigation, the brand will sue generic for patent infringement, even after the patent expired. Generally, courts find for generic manufacturers, often on summary judgment, and holds patents invalid or unenforceable. ${ }^{153}$ However, the result is really dictated by the Hatch-Waxman Act. Under the Hatch-Waxman Act, once the branded pharmaceutical company files a timely complaint, the FDA will not grant the generic company final approval of its product for thirty months, absent a court decision that the patent is not infringed, invalid, or unenforceable. ${ }^{154}$ Generics must prove the brand's infringement suit is objectively and subjectively baseless, but even so, once the branded company sues forty-five-days from the generics' patent application, the thirty-month stay is automatically triggered. ${ }^{155}$

Further, pharmaceutical manufacturers may potentially abuse the citizen's petitioning provisions promulgated by the FDA. ${ }^{156}$ In using this method, any person or entity, including a pharmaceutical company, may file a citizen petition with the FDA requesting that the agency take, or refrain from taking, any administrative action as long as the petition meets various requirements. ${ }^{157}$ When the petition is filed, the FDA refrains from approving the new generic

149 Id.; see, e.g., FED. TRADE COMM'N, Anticompetitive Practices (2015), https://www.ftc.gov/ [https://perma.cc/EQ8X-82QF].

${ }^{150}$ Schmitt, supra note 43, at 536-37.

${ }^{151}$ F.T.C. v. Actavis, Inc., 133 S.Ct. 2223, 2230 (2013) (emphasis added) (quoting F.T.C. v. Watson Pharm., 677 F.3d 1298 (11th Cir. 2012)).

${ }^{152}$ Linda Nussbaum \& John Radice, Pharmaceutical Antitrust: Delayed Generic Entry Cases, ANTITRUST InSTITUTE 1, 12 (Dec. 7, 2011), http://www.antitrustinstitute.org/ [https://perma.cc/NGU8-9N5F].

153 Id. at 14.

15421 U.S.C. $\S 355$ (2015).

${ }^{155}$ Federal Food, Drug, and Cosmetic Act, 21 U.S.C. § 355(j)(B)(5)(iii) (Westlaw through Pub.

L. No. 114-219).

${ }^{156}$ Nussbaum \& Radice, supra note 152, at 15.

${ }^{157}$ Federal Food, Drug, and Cosmetic Act, 21 U.S.C. § 355 (q)(1)(H). (Westlaw through Pub. L. No. 114-219). 
medication. ${ }^{158}$ This outcomes incentivizes pharmaceutical manufacturers to employ this stall tactic. For instance, "a party could embark on a strategy of filing baseless citizen petitions with the intent and effect of using the time in which it takes the FDA to respond to the petition to delay generic entry." 159

Lastly, pharmaceutical companies delay generic entry into the market by utilizing "product hopping." 160 Brand-name pharmaceutical companies avoid generic competition and preserve monopoly profits by combining minor product reformulations with efforts to damage or destroy the market for the original formulation. ${ }^{161}$ Though the strategy is apparent, the FTC has aggressively attacked this form of deliberate generic delay stating: "[p]roduct-hopping seems clearly to be an effort to game the rather intricate FDA rules .... The patentee is making a product change with no technological benefit solely in order to delay competition."162 As of 2013, only three substantive court decisions on the issue of product hopping. ${ }^{163}$ However, given the FTC's dedication to cut down attempts at delaying generic entry into the market, costly legislation may inspire the FTC to prioritize cases allowing for increased delay of certain generics in the market.

\section{VENTURE Philanthropy}

Traditionally, nonprofit organizations have been funded by foundations and government funds. ${ }^{164}$ However, as the focus of American priorities shifts to controlling the increasing cost of health care, government funding has been a less reliable source for most nonprofit organizations. In 2012, a survey reported that local, state and federal governments made up to $\$ 137$ billion in contributions to nonprofit organizations. ${ }^{165}$ However, once appropriated, these funds evaporated quickly and left many nonprofits with tough decisions on where to scale back or find additional funding. ${ }^{166}$ In pursuing elusive funding, nonprofits began entering into partnerships with for-profit entities, ${ }^{167}$ or started refining their programs and strategic reorganization in order to receive

158 See generally Seth Silber et al., Abuse of the FDA Citizen Petition Process: Ripe for Antitrust Challenge?, Antitrust Health CARE Chron. 26, 28 (January 2012), https://www.wsgr.com/publications/ [https://perma.cc/CZ8Z-8W4H].

${ }^{159}$ Id. at 28.

${ }^{160}$ FTC Files Amicus Brief Explaining that Pharmaceutical "Product Hopping” Can Violate the Antitrust Laws, FED. TRADE COMMISsION (Oct. 1, 2015), https://www.ftc.gov/ [https://perma.cc/PP99-DW8E].

${ }^{161} \mathrm{Id}$.

162 M. Shean Royall et al., Antitrust Scrutiny of Pharmaceutical "Product Hopping," 28 Antitrust 71, 76 (Fall 2013) (citing Brief for F.T.C. as Amicus Curiae at 1, Mylan Pharm., Inc., v. Warner Chilcott Pub. Co., No. 12-3824 (E.D. Pa. Nov. 21, 2012) quoting HerBerT HovenKamP ET AL, IP AND ANTITRUST, § 15.3 (15-75) (2d ed. 2010)).

${ }^{163} \mathrm{Id}$.

${ }^{164}$ Anita L. Horn, Venture Capital Philanthropy: The IRS and Treasury Hold The No-Cost Key

To The Growth Of Self-Sufficient Nonprofits January 2002, FED. B. ASS'N. SEC. OF TAX'N REP. 7

(Winter 2003).

165 Sarah L. Pettijohn et al., Urban Inst., NonProfit-Gov't CONTRACTS AND Grants:

FINDINGS FROM THE 2013 NAT'L SURVEY 4 (2013).

${ }^{166} \mathrm{Id}$.

${ }^{167}$ Horn, supra note 164 , at 11, n. 10 . 
program-related investments ("PRIs") from foundations and for-profit entities. ${ }^{168}$ In the pharmaceutical industry, the alignment of nonprofit organizations' pursuits for PRIs and pharmaceutical manufacturers' rising expenses has created the perfect climate for the growth of venture philanthropy activities.

Generally, venture philanthropy is "the process of adapting strategic investment management practices to the nonprofit sector to build organizations able to generate high social rates of return on their investments." 169 Venture philanthropy is an organizational activity that takes concepts and techniques from venture capital finance and business management and applies them to achieving philanthropic goals. ${ }^{170}$ Further, the concept of venture philanthropy started with a small group of "successful-entrepreneurs-turned-philanthropists" and has since erupted to include hundreds of foundations. ${ }^{171}$ In regards to the pharmaceutical industry, these foundations are lucrative in part, because of their tax advantages and missions, either through the foundations' own research or grant-making authority. ${ }^{172}$

The tax advantages for private nonprofits and foundations are established through a general federal tax exemption in 26 U.S.C. $§ 501$ (c)(3) ("Exemption"). ${ }^{173}$ Under the Exemption, a private foundation or nonprofit is exempt from federal income taxes. ${ }^{174}$ Importantly, however, private nonprofits and foundations utilize the "charitable, scientific, testing for public safety" language of the Exemption. ${ }^{175}$ As defined by the subsequent regulation, charitable purposes are those in "[r]elief of the poor and distressed or of the underprivileged . . . advancement of education or science . . . lessening of the burdens of Government; and promotion of social welfare by organizations designed to accomplish any of the above purposes. . .."176 Further, "scientific research will be regarded as carried on in the public interest . . . (c) If such research is directed toward benefiting the public ... [including] (3) scientific research carried on for the purpose of discovering a cure for a disease. ..." 177 Therefore, private foundations and nonprofit organizations, which fund or otherwise aid in the development of new prescription drugs to cure diseases, can

168 See generally LaVerne Woods, The Emergence of 'Venture Philanthropy' Raises New Tax Issues, 13 J. TAX'N OF EXEMPT ORG. 51, 1, 7 (Sept.-Oct.2001) (“A PRI is an investment, typically in the form of a loan or equity position, designed to further a charitable purpose."); see also Foundation Grants, GRANT SECRETS, http://www.grantsecrets.com [https://perma.cc/E4LE4HF6] (last visited March 10, 2016).

169 Horn, supra note 164, at 7 (citing Venture Philanthropy: The Changing Landscape 8, VENTURE PHILANTHRopy PARTNERS, (2001)).

170 Tara Weiss \& Hannah Clark, 'Venture Philanthropy' is the New Buzz in Business, FORBES.COM ON NBCNEWS.COM (Jun. 26, 2006, 2:59 PM), http://www.nbcnews.com/ [https://perma.cc/L4W8-KAP2].

${ }^{171}$ Garry W. Jenkins, Who's Afraid of Philanthrocapitalism?, 61 CASE W. RES. L. REV. 753, 757 (2011).

172 The Private Foundation, FINDLAw, http://corporate.findlaw.com/ [https://perma.cc/4F3EFTWH] (last visited Jan. 29, 2016).

17326 U.S.C. § 501(c)(3) (Westlaw through Pub. L. 114-219).

${ }^{174} \mathrm{Id}$.

${ }^{175} \mathrm{Id}$.

17626 C.F.R. $\$ 1.501(\mathrm{c})(3)-1(\mathrm{~d})(\mathrm{iii})$ (2014); See Example 3: (2) Charitable defined.

17726 C.F.R. § 1.501(c)(3)-1(d)(iii)(5)(iii) (2014); See Example 4: (5)(iii). 
organize under the statute to utilize the Exemption. ${ }^{178}$ Thus, ultimately having income tax advantages of allowing donations to the private nonprofits in exchange for income tax deductions, and the earnings of the foundation will not be taxed so long as the earnings are related to the foundation's charitable purpose. ${ }^{179}$

Finally, the law does not necessarily prohibit self-dealings in venture philanthropy amongst private foundations, and an otherwise disqualified individual ${ }^{180}$ insomuch as the proceeds from the self-dealing are for the charitable purposes previously mentioned above. ${ }^{181}$ As pertaining to the prescription drug consumers, the emerging venture philanthropy model in the pharmaceutical industry may be the light at the end of the tunnel or, perhaps, an oncoming train.

Although more prominent in other industries, ${ }^{182}$ venture philanthropy has been a concept that has aided in the production of pharmaceuticals since the $1990 \mathrm{~s} .{ }^{183}$ By pairing with private nonprofit foundations, pharmaceutical companies have exploited an opportunity to fund initial research of drugs that potentially solve global health issues. ${ }^{184}$ With notable nonprofits like the Michael J. Fox Foundation, the Leukemia \& Lymphoma Society ("LLS"), and the Multiple Myeloma Research Foundation ("MMRF") being a few years into efforts to fund drug development using the venture philanthropy model, weighing the potential abuses and potential benefits will aid in assessing whether or not the venture philanthropy model can be a sustainable solution to rising drug costs. 185

\section{A. Potential Abuses}

178 See John Fauber, Cystic Fibrosis: Charity and Industry Partner for Profit, MEdPAGE TODAY (May 19, 2013), http://www.medpagetoday.com/ [perma.cc/5HJF-JY4Z].

${ }^{179}$ Horn, supra note 164, at 8; see also The Private Foundation, supra note 172.

${ }^{180}$ The Private Foundation, supra note 172 ("A disqualified person is any officer, director, trustee, or any employee of the private foundation and also includes any substantial contributor. Disqualified persons ... includes all family members of the disqualified person ... and can include corporations, partnerships or other business interests in which a disqualified person has an ownership interest").

${ }^{181}$ Loans, IRS.GOV, https://www.irs.gov/ [https://perma.cc/RKK3-54QH]. (last updated Mar. 18, 2016)) (“. . . this does not include lending money by a disqualified person to a private foundation without interest or other charge if the borrower uses the loan proceeds exclusively for purposes specified in section 501(c)(3) of the Code"); see also Taxes on Self-Dealing, 26 U.S.C. $\S$ 4941(d)(2)(B) (Westlaw through Pub. L. 114-219).

182 See generally Jenkins, supra note 172, at 761 (referring to both the Bill and Melinda Gates Foundation and the Warren Buffet Foundation's tackling other social challenges).

${ }^{183}$ Anne M. Readel, Finding A Cure: Incentivizing Partnerships Between Disease Advocacy Groups and Academic and Commercial Researchers, 26 J.L. \& HEALTH 285, 290 (2013).

${ }^{184}$ See Jon C. Mirsalis, The Role of Nonprofit Institutes in Pharmaceutical Development, SRI InTERNATIONAL BLOG (Sep. 13, 2012, 1:20 PM), https://www.sri.com [https://perma.cc/U766$\mathrm{D} 3 \mathrm{CB}$ ] (asserting that SRI [nonprofit foundation] advanced malaria drug from research to clinical phases).

${ }^{185}$ Lisa M. Jarvis, Advanced R\&D By Venture Philanthropy, 90 CHEM. \& ENG'G News (Nov. 5, 2012), http://cen.acs.org/ [https://perma.cc/CHE9-SG4Q]. 


\section{Pharmaceutical Companies Creating Their Own Philanthropies Then Funding Them}

Many critics of the venture philanthropy model argue that the ease of creating and terminating a private nonprofit foundation can lead to the creation of many tax-exempt foundations that receive donations to create blockbuster drugs for rare diseases. ${ }^{186}$ As one scholar suggested, "[t]here is nothing to stop pharmaceutical companies from creating their own philanthropies, funding research with tax-exempt dollars and then selling themselves the rights to the intellectual property. Without price controls on the final product that come with public funding, the potential costs of the resulting medicines are limitless."187

The process of incorporating a private nonprofit foundation is a relatively simple process involving filing articles of incorporation, selecting board members, devising a mission or purpose, creating bylaws, opening a bank account, and finding office space for the newly recruited members. ${ }^{188}$ Once the private nonprofit foundation is established it can choose to pursue its mission through advocacy, allocating funding, or conducting research. ${ }^{189}$ Finally, "[t]he private foundation can be ended anytime by simply distributing the foundation assets to a charity. . .."190

Consider the following scenario: A pharmaceutical establishes a private nonprofit foundation, in which the foundation then raises funds from public and private entities, including the original pharmaceutical company. Then the same foundation uses tax-exempt resources to develop the drug, and ultimately selling the results to the pharmaceutical company. ${ }^{191}$ Therefore, critics mention that a reasonable fear exists that no safeguards in place for preventing pharmaceutical companies from creating countless nuanced foundations, which will have the ultimate effect of privatizing scientific research for blockbuster drugs of rare, but profitable, diseases. ${ }^{192}$ Further, although the research and development were in part, or in its entirety, funded by charitable donations, the final price of the product is not guaranteed to be more affordable than it otherwise would have been.

\section{Limiting the Field of Ideas to the Ideas Heavily Funded by Corporations}

Secondly, use of the venture philanthropy model may create corporate driven initiatives that exclude traditional donors. ${ }^{193}$ The consistent demand for funding in nonprofits may cause them to emphasize more profitable activities at the expense of other more traditional, less lucrative activities. ${ }^{194}$ This activity is demonstrated by the growing number of "program support" grants

186 Llewellyn Hinkes-Jones, Stop Subsidizing Big Pharma, N.Y. Times (Jan. 5, 2015), http://www.nytimes.com [https://perma.cc/5Z55-JXJ5].

${ }^{187}$ Id.

188 See Establishing a Nonprofit Organization, FOUNDATIONCENTER.ORG, http://foundationcenter.org/ [https://perma.cc/ZBF9-D9W8] (last visited Jan. 30, 2016) (contains a walkthrough of how to establish a nonprofit organization and provides sample documents that may need to be filed).

189 The Private Foundation, supra note 172.

${ }^{190} \mathrm{Id}$.

${ }^{191}$ Hinkes-Jones, supra note 186.

${ }^{192}$ Id.

193 Jenkins, supra note 182, at 762.

${ }^{194} \mathrm{Id}$. at 761, 763. 
issued by for-profit businesses to charitable foundations. 195 "These "program support" grants restrict the uses of money to a greater degree than "general support" grants, which nonprofits may use at their discretion for a variety of purposes." 196 If a large for-profit entity provides lucrative narrow program support grants, then the nonprofit foundation will be more likely to engage in that activity whereby it also uses the donated funds received from the general public. Venture philanthropy structure has often drawn comparison to the manager-subordinate corporate relationship. ${ }^{197}$ This kind of relationship may threaten "to turn grant-seeking charities into constrained participants without full recognition of their value, autonomy, and expertise."198

Additionally, advocating this kind of relationship may decrease public participation in charitable giving and further "advances the concentration of power and influence in the hands of small numbers of the wealthiest Americans: an elite set of philanthrocapitalists relying on their personal views and business experience to select social solutions for the rest of society." 199 "When the general public donates to a foundation in furtherance of its mission, one could surmise, these individuals seldom expect the foundation to act on behalf of the prerogative of a for-profit business. Thus, some fear venture philanthropy may lead to a general distrust in the foundations and fewer public donations. Therefore, if for-profit entities suddenly are the only charitable donors, in the form of program support grants, then those entities could potentially prioritize society's social issues. $^{200}$

\section{B. Potential Benefits}

Despite the multitude of models and potential for abuse, advocates of the venture philanthropy model postulate that these relationships between private and public nonprofit foundations create unique opportunities to lower costs of prescription drugs while increasing research and development efficiency. ${ }^{201}$ Additionally, these business partnerships may further incentivize pharmaceutical companies to repurpose previously developed drugs to treat other illnesses.

\section{Increase Innovation Through Nonprofit Funding of Research and Development.}

The top five pharmaceutical companies in the United States are all publicly owned. ${ }^{202}$ Thus, these for-profit companies invest to increase shareholder value. ${ }^{203}$ In pharmaceuticals, the focus on profit often leads to products that lack innovation, but instead yield a "high economic return."204

${ }^{195}$ Id. at 776.

${ }^{196}$ Id.

${ }^{197}$ Id. at 769.

${ }^{198} \mathrm{Id}$.

${ }^{199}$ Id. at 816.

${ }^{200}$ See generally id. at 817.

201 See generally Readel, supra note 183, at 286-90.

202 See generally Companies in North America, NASDAQ, http://www.nasdaq.com/ [https://perma.cc/NMJ8-DKRU] (last visited Aug. 28, 2016) (Novartis, Pfizer, roche, Sanofi, and Merck \& Co.).

203 See Mirsalis, supra note 184.

${ }^{204}$ Benjamin E. Klein \& Kathryn J. Dalby, Nonprofit Drug Companies, 24 HeALTH AfF. 1684, 1684-85 (2005), http://content.healthaffairs.org/ [https://perma.cc/2CUP-DJKE]. 
Conversely, nonprofit foundations operate in furtherance of their mission and do not tailor decisions based on profit expectations. ${ }^{205}$ Therefore, nonprofit institutes do not lack an incentive to not create innovative medicines that are unprofitable or otherwise seen as risky investments. ${ }^{206}$

Apart from supporting innovation of new medicines, a venture philanthropy model can reduce pharmaceutical manufacturer's substantial individual research and development expenses. Advocates, recognizing the funding limitations of nonprofits, assert "[a]lthough still a small part of drug R\&D financing, venture philanthropy has become an important way to bridge the funding gap between preclinical studies and early tests in patients." ${ }^{207}$ Commonly, nonprofits, in accordance to their mission, will invest millions of dollars to the research process that can require up to $\$ 5$ billion. ${ }^{208}$ However, the multi-million dollar "remov[es] enough uncertainty around some drug targets to entice other companies to invest in similar R\&D.",209

Alternatively, if pharmaceutical manufacturers prefer to outsource some of the research to a private operating nonprofit foundation, ${ }^{210}$ then these nonprofit operating foundations may build coalitions with other public charities, foundations, and governmental agencies to further fund a therapeutic consistent with its mission. ${ }^{211}$ Subsequently, a nonprofit will use this funding to take a drug from initial research to early clinical trials. ${ }^{212}$ This process requires a detailed plan, which on its own may cost anywhere between $\$ 3$ million and $\$ 10$ million). ${ }^{213}$ In return for its expertise and donations, the pharmaceutical manufacturer will typically have the first opportunity to patent the new drug. ${ }^{214}$ Further, this partnership style has already demonstrated success. SRI International, a nonprofit operating research foundation, aided in moving over 150 drug compounds from the discovery to research stage-over twelve of which eventually made it to market. ${ }^{215}$ The success of the venture philanthropy model is not limited to the discovery of new compounds as it provides an opportunity for pharmaceutical manufacturers to repurpose marketed drugs.

\section{Economic Repurposing of Drugs}

Although a complete discussion of off-label prescribing and the intricacies of repurposing are too expansive to include in this Note, but it is important to mention that the ill effects of off-label

${ }^{205} \mathrm{Id}$.

206 See generally Mirsalis, supra note 184 (noting that the nonprofit, SRI, advanced therapeutics to treat malaria that is rampant in underdeveloped countries).

207 Jarvis, supra note 185.

208 See generally Matthew Herper, The Cost Of Creating A New Drug Now \$5 Billion, Pushing Big Pharma To Change, ForBES (Aug. 11, 2013, 11:10 AM), http://www.forbes.com [https://perma.cc/4WWT-EBBM].

209 Jarvis, supra note 185.

${ }^{210}$ See generally Definition of a Private Operating Foundation, IRS.GOV, https://www.irs.gov/ [https://perma.cc/99VN-UDEX] (last updated April 29, 2016 ("A private operating foundation is any private foundation that spends at least 85 percent of its adjusted net income or its minimum investment return, whichever is less, directly for the active conduct of its exempt activities").

${ }^{211}$ Mirsalis, supra note 184.

${ }^{212} \mathrm{Id}$.

${ }^{213} \mathrm{Id}$.

214 See generally Jarvis, supra note 185.

${ }^{215}$ Mirsalis, supra note 184. 
prescriptions cost the health care system $\$ 100$ billion to $\$ 300$ billion annually. ${ }^{216}$ According to PhRMA, "A focus on improving quality of care and adherence to evidence-based best practices . . . can help improve the way medicines are used. Evidence shows that proper use of medicines can be one of the most effective ways to achieve better health outcomes and reduce costs." 217 Therefore, safely repurposing prescription drugs in order to limit the ill effects of off-label prescribing can greatly reduce overall health care costs which may allow for greater investment in innovative medicine.

Proponents of the venture philanthropy model argue that the partnerships between nonprofits and pharmaceutical manufacturers will further incentivize the repurposing of drugs commonly being used off-label. ${ }^{218}$ According to the FDA, "[b]ecause repurposing builds upon previous research and development efforts, new candidate therapies could be ready for clinical trials quickly, speeding their review by the FDA and, if approved, their integration into health care."219 Further, pharmaceutical manufacturers can obtain a "method of use" patent and will have market exclusivity for about three years for a new chemical formulation. ${ }^{220}$ Previous repurposing efforts appeared costly considering the legal alternative was to allow sales representatives to advocate that the drugs prescribed be used for off-label use. ${ }^{221}$ However, armed with nonprofit funding and PhRMA's new initiative for adherence to prescribed medicines, the venture philanthropy model may be another way to incentivize pharmaceutical companies to repurpose certain drugs. Further, repurposing certain prescription drugs may limit off-label prescribing and its costs to the health care system.

\section{Example: Cystic Fibrosis Foundation Collaboration with Vertex Pharmaceuticals}

A seminal example, that demonstrates potentials for abuse and tremendous benefits of the venture philanthropy model between a nonprofit and a pharmaceutical manufacturer, was recently concerted by Vertex Pharmaceuticals and the Cystic Fibrosis Foundation ("the Foundation"). ${ }^{222}$ The collaboration created Kalydeco, a "breakthrough" prescription drug that treats the orphan disease $^{223}$ cystic fibrosis, and can be summarized as follows: "Vertex developed the drug with the

216 PhRMA Statement on Healthcare Reform Coalition, PHRMA (May 11, 2009), http://www.phrma.org/ [https://perma.cc/V22U-L75H].

${ }^{217}$ Id.

${ }^{218}$ Salbu, supra note 132, at 192-94.

219 Repurposing Drugs, NAT'L INST. OF HEALTH, http://ncats.nih.gov/preclinical/repurpose [https://perma.cc/SNV8-6Y67] (last visited Aug. 28, 2016).

220 Patent Tips for Small Pharma Companies, COJK.COM, http://www.cojk.com/ [https://perma.cc/F4EZ-W73S] (last visited Aug. 28, 2016).

${ }^{221}$ Daniel S. Sem, Repurposing - Finding New Uses for Old (and Patented) Drugs: Bridging the "Valley of Death," to Translate Academic Research Into New Medicine, 18 MARQ. INTELL. PROP. L. REV. 143, 146, 163-64 (2014).

${ }^{222}$ Readel, supra note 184 , at 286-87.

223 Orphan Products: Hope for People With Rare Diseases, U.S. FoOd \& DRUG ADMIN., http:/www.fda.gov/Drugs/ResourcesForYou/Consumers/ucm143563.htm

[https://perma.cc/GN9P-CVT6] (last visited Aug. 28, 2016) ("An orphan disease is defined as a condition that affects fewer than 200,000 people nationwide"); see also Fauber, supra note 179 ("About 30,000 people in the U.S. have cystic fibrosis"). 
help of a \$75 million investment from the Cystic Fibrosis Foundation -- as well as a hefty investment from taxpayers through grants from the National Institutes of Health, which underwrote the cost of early research, which identified the gene that the drug targets." 224 The Foundation has since reportedly asked for a portion of the income resulting from sales and sold a minor portion of their rights to royalties for about $\$ 150$ million dollars. ${ }^{225}$ In utilizing the $\$ 150$ million, the Foundation then invested in other drug development projects with the pharmaceutical giants, Pfizer and Genzyme. ${ }^{226}$

Vertex, on the other hand, is recouping other affiliated costs of bringing Kalydeco to market by charging a $\$ 307,000$ for a patient's yearly dose. ${ }^{227}$ However, Nikki Levy, a spokeswoman for Vertex, said: "the vast majority of patients pay between $\$ 15$ and $\$ 50$ a month out-of-pocket for Kalydeco." 228 Although more reasonable than the reported yearly cost per patient, the statement makes one wonder who, or what, will make up the difference. Doctors from the American Medical Association offer that these costs are merely transferred to the federal or private insurers, but believe this will not solve the problem. ${ }^{229}$

From the recent collaboration between the Foundation and Vertex, a person could suppose that current venture philanthropy models may provide: (1) an increase in funding for research and development of prescription drugs, and (2) an increase in prescription drugs being brought to market. ${ }^{230}$ On the other hand, the recent partnership also demonstrated limitations regarding price control, even though costly research and development had been supported by public funds. ${ }^{231}$ From the inherent limitations posed in the partnership between the Foundation and Vertex, one could foresee increasing prevalence of abusing this venture philanthropic model.

Ultimately, the public will likely not benefit from the lack of partnerships between pharmaceutical companies and private nonprofit foundations using the venture philanthropy model. Instead, policymakers should encourage these partnerships but also mandate increased accessibility to consumers.

\section{ANALYSIS (POLICY IMPLEMENTATION)}

\section{A. Federal Tax Re-evaluation for Pharmaceutical Representatives}

Through sales representatives, pharmaceutical manufacturers "detail" doctors in order to influence prescribing habits contributing to the growing prescription drug prices. ${ }^{232}$ For example, pharmaceutical manufacturers provide more than $\$ 5.7$ billion worth of drug samples to $90 \%$ of physicians in the United States each year. ${ }^{233}$ Since detailing is accounted as a marketing expense,

${ }^{224}$ Fauber, supra note 178.

${ }^{225}$ Id.

${ }^{226} \mathrm{Id}$.

${ }^{227}$ Id.

228 John Fauber, Kalydeco: A Price Too High To Pay, MedPage Today (Oct. 2, 2013), http://www.medpagetoday.com/ [https://perma.cc/KM8E-92E5].

229 See id.

230 See Readel, supra note 183, at 298.

${ }^{231}$ Fauber, supra note 178.

232 See Prescription Project, supra note 79.

${ }^{233}$ Id. 
the company must offset that expense either through more sales or higher prices. If the pharmaceutical company does not have a blockbuster product that year, it will follow that the companies resort to price increases to compensate for these marketing expenses.

Because detailing comprises much of the pharmaceutical manufacturers' marketing expenses; ${ }^{234}$ these increased expenses contribute to higher prescription drug prices, and state attempts to limit detailing expenses have proven nominally effective. Therefore, this Note will submit a two-pronged policy amendment at the federal level.

Prong one of this Note's suggested policy amendments proposes is to alter tax provisions of pharmaceutical representatives who have a tax rate of $28 \%$ or higher, in order to limit what may be written off as a business expense. Specifically, travel expenses such as lodging, operating and maintaining a representative's vehicle, and transportation, as defined in IRS Publication 463, would no longer be available as tax deductions. ${ }^{235}$ Additionally, vaguely similar to Section 6008 of the $\mathrm{ACA},{ }^{236}$ implementing a tax on a small percentage of marketing expenditures over \$20 billion may be beneficial.

The amendment would incentivize pharmaceutical representatives to engage in alternative detailing measures, such as e-detailing ${ }^{237}$, by not allowing those whose income is taxed at a level of $28 \%$ or higher to write off ordinary travel expenses. Alternatively, employers may absorb those costs in order to continue marketing their products in the traditional manner. Coupled with the imposition of a small tax on a percentage of marketing expenditures, pharmaceutical manufacturers could be financial incentivized to develop more cost-effective marketing techniques or reduce the size of their marketing departments. The latter has notably been occurring with the passage of the sunshine provisions in the ACA and the increased usage of e-detailing. ${ }^{238}$ However, this did lead to an overall decrease in physician payments of about $\$ 1,000$ per physician. ${ }^{239}$ Although reducing the number of pharmaceutical representatives may be unfavorable to the public, it could be the result of a necessary evil that may provide more affordable prescription drugs.

Together, these tax amendments could require pharmaceutical manufacturers and their sales representatives to consider more economically feasible alternatives to traditional detailing. In turn, less money may be required to effectively market prescription drugs that can then be reinvested into research and development. Foreseeably, extra funding for research and development will either result in new blockbuster drugs or prescription drug savings that are passed along to the consumers.

The next second prong would codify industry standards that the Pharmaceutical Research and Manufacturers of America [PhRMA] promulgated in 2002, which is the Revised PhRMA Code

${ }^{234} \mathrm{Id}$.

235 I.R.S., Dep't of the Treasury, Cat. No. 11081L, Travel, Entertainment, Gift, and Car Expenses, IRS.GOV, 1, 5 (2015), https://www.irs.gov [https://perma.cc/R9VN-8F8X].

${ }^{236}$ H.R. 34, $114^{\text {th }}$ Cong. (2016)(enacted).

237 Online physician marketing, promotional and communication activities.

238 See Thomas Sullivan, Physician Payment Sunshine: Some Pharmaceutical Companies Reduced Meal Payments to Health Care Providers, PoL'y AND Med. (Apr. 22, 2013), http://www.policymed.com/ [https://perma.cc/XP9P-WDML] (noting that Pfizer reduced spending on detailing which led to some reduction in the workforce).

${ }^{239}$ Id. 
("Code"). ${ }^{240}$ The Code was adopted in order to "reinforce [PhRMA member's] intention that interactions with health care workers are professional exchanges designed to benefit patients and to enhance the practice of medicine." ${ }^{241}$ Generally, the Code creates an ethical compliance program for PhRMA manufacturers, in that each pharmaceutical manufacturer is encouraged to certify compliance with the Code annually. ${ }^{242}$

However, there are no penalties for non-compliance with the Code aside from the PhRMA not publishing a pharmaceutical manufacturer's name on a list that is accessible to the public. ${ }^{243}$ To add teeth to the Code, this Note suggests giving it the force of law or codifying it so that there may be penalties associated for non-compliance with industry standards.

\section{Why Regulate Pharmaceutical Promotion?}

In pharmaceuticals "Promotion is a key factor driving sales volumes," and "[t]he greater the volume of medicines sold, the greater the return on investments." ${ }^{244}$ By regulating pharmaceutical manufacturers marketing efforts, the government would guide the pharmaceutical industry into more cost-effective marketing practices, thereby leading to better health outcomes, such as greater access to prescription drugs. ${ }^{245}$ Further, regulating promotional efforts would be highly favorable amongst a majority of United States citizens, since it would potentially lower prescription drugs costs. $^{246}$

\section{B. Use of Modified Venture Philanthropy}

In addressing the potential abuses and benefits of using the venture philanthropy model, the federal government can potentially utilize a model that spurs innovation, decreases prescription drug costs, and may lead to more actual results. ${ }^{247}$ With an effective policy to limit the potential for abuses and a reasonable degree of oversight, an incentivized use of a modified venture philanthropy model may be what effectively ostracizes drug spiking behavior while reaffirming the free-market approach.

\section{Utilizing Private Nonprofit Foundations with "Program-Support” Grants}

${ }^{240}$ Code on Interactions with Healthcare Professionals, THE PHARM. RESEARCH \& MFr. OF AM. 1, 2-3 (2008), http://www.phrma.org/ [https://perma.cc/BM8E-Y8B3].

${ }^{241} I d$. at 2.

${ }^{242}$ Id. at 14.

${ }^{243} \mathrm{Id}$.

244 Joel Lexchin \& Lilia Ziganshina, Regulation of Pharmaceutical Promotion: Why Does Regulation Matter?, POL. OF MED. http://www.politicsofmedicines.org [https://perma.cc/7YMTREGU] (last visited Jan. 1, 2016).

245 Id.

246 Matthew Perrone, Poll: Americans' No. 1 health priority is keeping critical drugs affordable for patients, ABCNEws U.S. NEWS \& WORLD REP. (Oct. 28, 2015, 3:44 AM), http:// www.usnews.com/ concerns [https://perma.cc/K9TU-SSAX].

${ }^{247}$ See generally Horn, supra note 164, at 11 (see generally $\S$ III). 
As of 2015, there were about 103,430 registered private nonprofit foundations, about 16,000 of which were operating foundations. ${ }^{248}$ As noted earlier, operating foundations are those any private foundation that spends at least 85 percent of its adjusted net income or its minimum investment return, whichever is less, directly for the active conduct of its exempt activities. ${ }^{249}$ Of the 16,000 private operational foundations previously mentioned, an increasing number of nonprofit research institutes claim that they can provide comprehensive research and development services to "maximize [pharmaceutical manufacturers'] investment dollars while minimizing risk." ${ }^{250}$ To an effect, these contractual partnerships may potentially have the same relationship as a "program-support" grant, by allowing commercial businesses to outsource all or certain aspects of the research and development process of certain product. ${ }^{251}$ These partnerships may be lucrative for pharmaceutical manufacturers because the full costs of research and development may be aided by other organizations and governmental entities; there will be no start-up costs associated with equipment and staffing overhead; small marketing initiatives from "nonprofit" have proven successful, and there is a potential for increased innovation in the pharmaceutical industry.

Exemplifying this approach is the Cystic Fibrosis Foundation and Vertex partnership for the cystic fibrosis drug, Kalydeco. Although these partnerships have the potential to drastically reduce the costs of developing a particular drug, the partnerships do not guarantee lower prices for the ultimate consumer. As seen with the drug, Kalydeco, a yearly treatment may ultimately cost the consumer around $\$ 300,000$, even though the cost of research and development was comparatively less due, in large part, to public funding. ${ }^{252}$

In order to remedy this situation, this Note suggest that legislation can effectuate policies that will protect predatory prices for consumers while providing the benefits of these kinds of partnerships. This Note advocates for an extended and modified sales fee schedule for generic and brand-name prescription drugs developed from nonprofit institutions pursuant to $\S 9008$ of the ACA. ${ }^{253}$ Specifically, an imposition of a federal tax of $2.5 \%$ on sales between $\$ 1$ to 2.5 million and $7.5 \%$ on sales between $\$ 2.5$ to 5 million at the end of each fiscal year may incentivize manufacturers to reduce the initial listing price. Because the imposition of a tax alongside any contractual obligations to the nonprofit may discourage pharmaceutical manufacturers to engage in these less profitable ventures, this Note advises that the tax should be accompanied by an optional, conditioned-provision regarding patent exclusivity. Ideally, this well-drafted condition would aim for longer patent exclusivity so long as the drug remained reasonably priced. ${ }^{254}$

248 Brice S. McKeever et Al., The Nonprofit Sector in Brief 2015: Public Charities, GIVING, AND VOLUNTEERING 3 (2016).

249 See Definition of a Private Operating Foundation, supra note 211.

250 Taking You From Idea to IND and Beyond, SRI BIOSCIENCES 1, 3, https://www.sri. [https://perma.cc/428X-7KXX] (last visited Mar. 10, 2016).

251 See id. at 3-7.

252 Fauber, supra note 178.

253 Section 9008 Patient Protection and Affordable Care Act (2010), amended by section 1404 of the Health Care and Education Reconciliation Act, Pub. L. No. 111-152, 124 Stat. 1029 (2010).

${ }^{254}$ To some effect, if a not-so-innovative drug makes it to market under this model, then the manufacturer with a patent can elect to obtain a traditional patent for up to eighteen years or a conditioned patent for a period beyond. 
Finally, it is important to note that $\S 9008$ of the ACA explicitly provides for an exception for orphan drugs in its fee schedule. ${ }^{255}$ Similarly, the proposed extensions would not apply to orphan drugs as tampering with the Orphan Drug Act may discourage manufacturers from developing the otherwise unprofitable drug. ${ }^{256}$ However, this Note suggests that capable nonprofits follow the lead of the Foundation and Vertex with their blockbuster orphan, Kalydeco. In 2013, this partnership agreed to provide medicine to insured persons at a 30\% discounted rate and at no cost for uninsured persons with income below $\$ 150,000 .^{257}$

\section{Creating Own Private, Operating, Foundations}

However, over-regulation of this partnership could lead to the pharmaceutical manufacturers establishing their private operating foundations, either jointly or individually. Further, subsequent private foundations could then declare themselves a "general-purpose" foundation, which would provide the private foundation with a broad public interest to advance. ${ }^{258}$ Although some may advocate that competition would prevent this kind of partnership, but as recently as 2012 , ten of the biggest pharmaceutical manufacturers formed a non-profit organization to accelerate the development of new medicines. ${ }^{259}$ This nonprofit, TransCelerate BioPharma, Inc., has a broad mission to share research that simplifies and accelerates new medicines to patients. ${ }^{260}$ Collaboratively, this coalition would have the means to create a general-purpose operating arm under TransCelerate BioPharma. However, it is likely that with multiple for-profit entities seeking market exclusivity, that such a joint endeavor may not be worth it. As noted as a potential abuse, the more concerning event may be the big pharmaceutical manufacturer that establishes a generalpurpose nonprofit of their own in order utilize tax incentives and extra funding. For some critics, the exploitation of this tax loophole is only a matter of time. ${ }^{261}$

If a big pharmaceutical manufacturer decides to invest the initial capital to start a nonprofit research organization, then federal policymakers will have the unique opportunity of allowing pharmaceutical manufacturers to outsource research and development, essentially, to themselves. For the companies large enough to indulge in the new model and in conjunction with

${ }^{255}$ Section 9008 Patient Protection and Affordable Care Act (2010), amended by section 1404 of the Health Care and Education Reconciliation Act, Pub. L. No. 111-152, 124 Stat. 1029 (2010).

${ }^{256}$ Gary A. Pulsinelli, The Orphan Drug: What's Right With It, 15 SANTA Clara COMPUTER \& High TECH. L.J. 299, 318 (1999).

${ }^{257}$ Readel, supra note 183 , at 312.

258 Pattie Johnson, Foundations: Overview, New GeORgIA ENCYClOPEDIA (Dec. 10, 2013), http://www.georgiaencyclopedia.org/ [https://perma.cc/4E24-EET3] ("The 'general-purpose' foundations, many of which still continue today, emerged in the early twentieth century. These foundations have large endowments and broad public purposes, enabling them to address major social issues").

259 Ten Pharmaceutical Companies Unite to Accelerate Development of New Medicines, PRNEWSWIRE (Sept. 19, 2012), http://www.prnewswire.com/ [https://perma.cc/E9DX-XNH6] (Abbott, AstraZeneca, Boehringer Ingelheim, Bristol-Myers Squibb, Eli Lilly and Company, GlaxoSmithKline, Johnson \& Johnson, Pfizer, Genentech (a member of the Roche Group,)and Sanofi).

${ }^{260} \mathrm{Id}$.

${ }^{261}$ Hinkes-Jones, supra note 187. 
TransCelerate's expedition of the research and development process, policymakers can allow for more efficient and transparent research and development.

Additionally, in order for this model to be profitable, the pharmaceutical manufacturer would have to engage in endeavors that appealed to very specific, or very broad, consumers in order extract funding from other sources. For example, tailored foundations such as Cystic Fibrosis Foundation would predominately invest in developments that pertain to benefiting people diagnosed with cystic fibrosis. On the other hand, if pharmaceutical manufacturers decide to conquer a something as burdensome as breast cancer, then they may draw large federal funds from agencies such as the National Institute of Health and, the newly formed, White House Cancer Moonshot Task Force. ${ }^{262}$ Also, the IRS explicitly states that all foundations must file annual reporting requirements that are available to the public. ${ }^{263}$ Therefore, it's more probable than not that the pharmaceutical manufacturer would engage in widely supported public endeavors while increasing transparency of their expenses.

However, in order to incentivize more pharmaceutical manufacturers to adopt a venture philanthropy model, legislators need to devise a solution to the inevitable patent cliff without forcing more delaying more generic entry. Therefore, it may be advantageous to create a patent cliff schedule that is inversely conditioned on the prescription drug price. For instance, if a pharmaceutical manufacturer produces a drug that greatly benefits colorectal cancer patients and prices the drug affordably, then the manufacturer's patent should retain market exclusivity for a longer period of time. One can infer, such a schedule will encourage the pharmaceutical manufacturer to hypothesize a price that is reasonable and will allow for the maximization of profit. If this incentive proved inadequate, then the treasury could choose not to enforce the sales tax imposed in $\S 9008$ for the initial two years the nonprofit's drug is on the market.

\section{CONCLUSION}

"If you want to be incrementally better: Be competitive. If you want to be exponentially better: Be cooperative." - Unknown

As this Note demonstrates, the struggle between the affordability, innovation, and access to prescription drugs is not a recent phenomenon in American history. Undoubtedly, a route to more affordable prescriptions drugs will inevitably be faced with hostility from lobbyists and concerned capitalists. However, the ideas "innovation," "affordability," and "profit" do not have to be mutually exclusive. Utilizing free market approaches together with carrot-and-stick initiatives may allow an increase in innovative medicines, limit expenses, moderate profitability, reduce costs; and most importantly, shift the focus improving the lives of millions. Further, by developing implausible relationships between previous antithetic sectors, we may find that our health system will move forward when both industries pull in the same direction. Encouraging the use of a modified venture philanthropy model through well-placed policies can help slow the skyrocketing costs of prescription drugs and generally help reduce costs of health care in the United States.

${ }^{262}$ Memorandum from President Barack Obama, The White House, White House Moonshot Cancer Task Force (Jan. 28, 2016) (on file with The Office of Press Secretary), https://www.whitehouse.gov [https://perma.cc/P2QL-ZT9U].

${ }^{263}$ Private Foundations, IRS.GOV, https://www.irs.gov/ [https://perma.cc/7C4E-TWZK] (last updated April 15, 2015). 